\title{
PENGARUH MODEL PEMBELAJARAN QUANTUM TEACHING PADA BENTUK PENILAIAN PORTOFOLIO BERBASIS KELAS DAN JENIS SEKOLAH TERHADAP KEMAMPUAN PEMECAHAN MASALAH MATEMATIKA SISWA
}

\author{
Sri Hartini \\ Universitas Wiralodra, Jalan Ir. H. Djuanda KM 3 Singaraja Indramayu, \\ hartini5511@yahoo.co.id
}

\begin{abstract}
ABSTRAK
Tujuan penelitian ini untuk mengetahui ada tidaknya pengaruh model pembelajaran Quantum Teaching pada bentuk penilaian portofolio berbasis kelas dan jenis sekolah serta pengaruh interaksinya terhadap kemampuan pemecahan masalah matematis siswa di sekolah dasar dan madrasah ibtidaiyah Indramayu. Metode yang digunakan adalah metode eksperimen dengan desain factorial $2 \times 2$. Model pembelajaran, bentuk penilaian dan jenis sekolah sebagai variabel perlakuan, dan kemampuan pemecahan masalah matematis sebagai variabel respon. Sampel penelitian adalah siswa kelas V SD Karang Anyar I \& II dan siswa kelas V MI PUI dan Al-Irsyad Indramayu yang ditentukan dengan cluster random sampling. Teknik analisis menggunakan ANAVA dua jalan untuk menguji pengaruh faktor utama (main effect) dan pengaruh faktor interaksi (interaction effect). Hasil penelitian disimpulkan bahwa (1) kelompok siswa sekolah dasar yang diberikan model pembelajaran Quantum Teaching pada bentuk penilaian potofolio berbasis kelas lebih efektif meningkatkan kemampuan pemecahan masalah matematis dibandingkan pada kelompok madrasah ibtidaiyah, (2) kelompok siswa yang diberikan model pembelajaran Quantum Teaching pada bentuk penilaian portofolio tampilan lebih efektif meningkatkan kemampuan pemecahan masalah matematis dibandingkan pada kelompok siswa yang diberikan bentuk penilaian portofolio dokumen. Disarankan dalam pembelajaran matematika hendaknya menjadikan model pembelajaran Quantum Teaching pada bentuk penilaian portofolio tampilan sebagai model pembelajaran
\end{abstract}

\begin{abstract}
The objective of the present research is to determine whether there is or not the effect of Quantum Teaching learning model on class- and school type-based portfolio assessment mode and its interaction effect on the mathematical problem solving ability of students in both elementary schools and madrasah ibtidaiyahs in Indramayu.The research method used was an experimental method with a $2 \times 2$ factorial design. Learning method, assessment mode, and school type were the treatment variables, and mathematical problem solving ability was respond variable. The research sample was grade-V students of SDs Karang Anyar I \& II and grade-V students of MI PUI and Al-Irsyad of Indramayu selected by a cluster random sampling. The analysis technique used was twoway ANAVA to test both main effect and interaction effect. From the research result it was concluded that (1) the elementary school student group treated with Quantum Teaching learning model with class-based portfolio assessment mode was more effective in enhancing mathematical problem solving ability than madrasah ibtidaiyah group, (2) the students group treated with Quantum Teaching learning model with display portfolio assessment mode was more effective in enhancing mathematical problem solving ability than the student group treated with document portfolio assessment mode. It was suggested that Quantum Teaching learning model with a display portfolio assessment mode should be made as a learning model prioritized in mathematics learning in schools.
\end{abstract}

Keywords: Quantum Teaching Learning, Portfolio Assessment, School 
yang diprioritaskan dalam pembelajaran matematika di sekolah-sekolah.
Type, Mathematical Problem Solving Ability.

Kata kunci: Pembelajaran Quantum Teaching,

Penilaian Portofolio, Jenis

Sekolah, Kemampuan Pemecahan

Masalah Matematika.

\section{How to Cite: Hartini, S. (2017). Pengaruh Model Pembelajaran Quantum Teaching pada Bentuk Penilaian Portofolio Berbasis Kelas dan Jenis Sekolah Terhadap Kemampuan Pemecahan Masalah Matematika Siswa. Mathline: Jurnal Matematika dan Pendidikan Matematika, Vol.2, No.2, 119-132.}

\section{PENDAHULUAN}

Penyelenggaraan pendidikan di sekolah diwujudkan dalam bentuk interaksi proses pembelajaran yang melibatkan guru sebagai pendidik dan siswa sebagai peserta didik. Dalam konteks penyelenggaraan pendidikan ini, guru dengan sadar merencanakan kegiatan pengajarannya secara sistematis dan berpedoman pada seperangkat aturan dan rencana tentang pendidikan yang dikemas dalam bentuk Rencana Pelaksanaan Pembelajaran (RPP) berdasarkan pada kurikulum. Konsep ini didukung oleh Husamah \& Setyaningrum (2013) yang mengungkapkan langkah tepat yang harus dilakukan oleh guru untuk menyongsong implementasi Kurikulum 2013 adalah dengan mempelajari, memahami dan selanjutnya mempraktekkan Desain Pembelajaran Berorientasi Pencapaian Kompetensi atau dikenal dengan Desain Sistem Instruksional Berorientasi Pencapaian Kompetensi (DSI-PK). DSIPK adalah gambaran proses rancangan sistematis tentang pengembangan pembelajaran baik mengenai proses maupun bahan pembelajaran yang sesuai kebutuhan dalam upaya pencapaian kompetensi. Untuk implementasi kurikulum pada Sekolah Dasar/Madrasah Ibtidaiyah (SD/MI), dilakukan secara bertahap mulai tahun pelajaran 2013/2014.

Kemampuan pemecahan masalah merupakan suatu kompetensi yang harus dikuasai siswa pada pembelajaran matematika, yang memungkinkan siswa memperoleh pengalaman menggunakan pengetahuan serta ketrampilan yang bersifat tidak rutin. Hal senada dikemukakan oleh Ormrod (2009) bahwa pemecahan masalah adalah menggunakan pengetahuan dan keterampilan untuk menjawab pertanyaan yang belum terjawab dan situasi yang sulit. Selanjutnya Solso, et al. (2005) menambahkan bahwa pemecahan masalah diuraikan menjadi enam tahapan yaitu: identification the problem, representation of the problem, planning the solution, execute the plan, evaluate the plan, and evaluate the solution. Sejalan dengan pendapat tersebut menurut Hendriana \& Soemarmo (2014) proses 
pemecahan masalah matematis berbeda dengan proses menyelesaikan soal matematika. Perbedaan tersebut terkandung dalam istilah masalah dan soal. Menyelesaikan soal atau tugas matematika belum tentu sama dengan memecahkan masalah matematika. Apabila suatu tugas matematika dapat segera ditemukan cara menyelesaikannya, maka tugas tersebut termasuk pada tugas rutin dan bukan merupakan masalah. Suatu tugas matematika digolongkan sebagai masalah matematika apabila tidak dapat segera diperoleh cara menyelesaikannya namun harus melalui beberapa kegiatan lainnya yang relevan. Pendapat tersebut hampir sama seperti yang dikatakan Polya yang dikutip Margono (2007) juga mengemukakan bahwa, ada empat tahapan pada pemecahan masalah matematis yaitu memahami masalah, merancang pemecahan masalah, menyelesaikan masalah, memeriksa kembali hasil. Oleh karena itu pemecahan masalah merupakan suatu tingkat aktivitas intelektual yang tinggi, dimana siswa didorong dan diberi kesempatan untuk berinisiatif dalam menghadapi suatu masalah. Adapun salah satu tujuan belajar matematika adalah mengembangkan kemampuan pemecahan masalah. Beberapa kegiatan dalam proses pemecahan masalah matematka menurut Hendriana \& Soemarmo (2014) yaitu: mengidentifikasi kecukupan unsur untuk peyelesaian masalah, memilih dan melaksanakan strategi untuk menyelesaikan masalah, melaksanakan perhitungan, dan menginterpretasi solusi terhadap masalah semula serta memeriksa kebenaran solusi. Selanjutnya masalah menurut Shadiq (2014) merupakan pertanyaan yang menuntut untuk dijawab atau direspon, akan tetapi tidak semua pertanyaan akan merupakan suatu masalah. Suatu pertanyaan akan menjadi masalah hanya jika pertanyaan itu menunjukkan adanya tantangan (challenge) yang tidak dapat dipecahkan oleh suatu prosedur rutin (routine procedure) yang sudah diketahui si pelaku. Seperti yang dinyatakan Cooney, et al. yang dikutip Shadiq (2014), ".for a question to be a problem, it must present a challenge that cannot be resolved by some routine prosedure known to the student".

Peran matematika di dalam kehidupan mulai dari aktifitas sehari-hari sampai dengan pengembangan ilmu pengetahuan dan teknologi (IPTEK) sangatlah penting. Perkembangan IPTEK yang pesat menuntut peningkatan penguasaan kemampuan matematika bagi warga masyarakat. Hadi (2005) menyatakan bahwa ilmu pengetahuan dan teknologi yang dicapai saat ini banyak ditunjang oleh penemuan matematika. Selanjutnya Wijaya (2012) mengungkapkan pencapaian siswa Indonesia dalam PISA (Programme for International Student Assessment) Matematika sangatlah rendah dan dengan menggunakan hasil PISA tersebut dapat dipakai untuk memperbaiki kualitas 
pendidikan serta melakukan refleksi atas praktek pembelajaran matematika yang selama ini kita lakukan. Seperti yang dikatakan oleh Suriasumantri (2009) bagi dunia keilmuan matematika mempunyai peran sebagai bahasa simbolik yang memungkinkan terwujudnya komunikasi yang cermat dan tepat, sehingga dalam hubungannya dengan komunikasi ilmiah mempunyai peran ganda, yaitu sebagai ratu dan sebagai pelayan ilmu.

Selanjutnya menurut Wittgenstein yang dikutip oleh Suriasumantri (2009) menyatakan bahwa matematika adalah metode berpikir logis, sehingga dalam menghadapi masalah logika yang semakin lama semakin rumit dan membutuhkan struktur analisis yang lebih sempurna, maka logika berkembang menjadi matematika. Mengingat pentingnya pemecahan masalah dalam pembelajaran matematika tersebut maka masalah yang diberikan kepada siswa untuk diselesaikannya harus sesuai dengan tingkat perkembangan intelektual dan latar belakang pengetahuannya. Seperti yang dikatakan Hudojo (1988) bahwa berpikir matematika merupakan kegiatan mental yang tinggi. Karena itu berpikir matematika akan menyangkut struktur mental, yaitu dengan sasaran kepada hubungan, pola, bentuk dan struktur. Dan menurut Johnson \& Rising (1987), matematika adalah pola berpikir, pola mengorganisasikan, pembuktian yang logik, dan bahasa yang digunakan dengan istilah yang didefinisikan dengan cermat, jelas dan akurat. Selanjutnya menurut Soedjadi (2000), matematika ditinjau dari obyeknya jelas bukanlah merupakan benda konkret, tetapi berupa benda pikiran yang abstrak yang diklasifikasikan menjadi fakta, konsep, operasi ataupun relasi, dan prinsip. Menurut para ahli pendidikan matematika yang dikutip oleh Shadiq (2014), matematika adalah ilmu yang membahas pola atau keteraturan (pattern) dan tingkatan (order). Hal ini menunjukkan bahwa guru matematika harus memfasilitasi siswanya untuk belajar berpikir melalui keteraturan (pattern) yang ada. Sejalan dengan pendapat tersebut menurut Hendriana \& Soemarmo (2014) proses pemecahan masalah matematis berbeda dengan proses menyelesaikan soal matematika. Perbedaan tersebut terkandung dalam istilah masalah dan soal. Menyelesaikan soal atau tugas matematika belum tentu sama dengan memecahkan masalah matematika. Apabila suatu tugas matematika dapat segera ditemukan cara menyelesaikannya, maka tugas tersebut termasuk pada tugas rutin dan bukan merupakan masalah.

Pembelajaran Quantum Teaching merupakan model pembelajaran dengan karakteristik umum yang dapat memantapkan dan menguatkan sosialnya. Prinsip Quantum Teaching yang dikemukan oleh DePorter, et al (2002), ada lima prinsip yaitu: 1) Segalanya berbicara; 2) Segalanya bertujuan; 3) Pengalaman sebelum pemberian nama; 4) 
Akui setiap usaha;dan 5) Jika layak dipelajari, maka layak pula dirayakan. Selanjutnya DePorter, et al (2002), menambahkan bahwa Quantum Teaching berfokus pada hubungan yang dinamis dalam lingkungan kelas dengan interaksi yang mendirikan landasan dan kerangka untuk belajar.

Penilaian portofolio menurut Popham (1995) merupakan penilaian secara berkesinambungan dengan metode pengumpulan informasi atau data secara sistematik atas hasil pekerjaan siswa dalam kurun waktu tertentu. Selanjutnya menurut Fosters dan Masters yang dikutip oleh Surapranata (2006) membedakan penilaian portofolio kedalam tiga bentuk, yaitu: portofolio kerja (working portfolio), portofolio penampilan (show portfolio), dan portofolio dokumentasi (documentary portfolio), sedangkan Butler \& McMunn (2006) menyatakan beberapa tipe portofolio yaitu: best work, memorabilia, growth, skill, dan assessment proficiency, or promotion portfolio. Menurut Cole, et al (1995) mengelompokkan jenis portofolio ke dalam dua jenis, yaitu: portofolio proses dan portofolio produk. Portofolio produk dibagi menjadi portofolio tampilan dan portofolio dokumen.

Menurut Surapranata (2006) portofolio tampilan digunakan untuk tujuan seperti seleksi, sertifikasi, maupun penilaian kelas. Portofolio tampilan ini juga dijelaskan oleh Cole, et al (1995) sebagai sekumpulan hasil kerja siswa atau dokumen yang terseleksi yang dipersiapkan untuk ditampilkan di depan umum. Adapun penilaian portofolio dokumentasi menurut Surapranata (2006) adalah koleksi hasil kerja siswa yang khusus digunakan untuk penilaian, atau koleksi dari sekumpulan hasil kerja siswa selama kurun waktu tertentu.. Selanjutnya menurut Arifin (2009) isi portofolio harus menyajikan suatu bukti yang berkaitan dengan kompetensi dasar dan indikator pencapaian kemampuan pemecahan masalah matematis yang telah ditentukan.

Model-model pembelajaran dan bentuk-bentuk penilaian portofolio tersebut diatas diterapkan pada sekolah dasar dan madrasah ibtidaiyah terhadap kemampuan pemecahan masalah matematis siswa. Setiap model pembelajaran dan bentuk penilaian portofolio tersebut belum tentu cocok dengan kemampuan pemecahan masalah matematis siswa sekolah dasar ataupun madrasah ibtidaiyah. Oleh karena itu, penelitian ini bertujuan untuk mengkaji pengaruh penerapan model pembelajaran dan bentuk penilaian portofolio berbasis kelas terhadap kemampuan pemecahan masalah matematis siswa.

Kaitan antara proses pembelajaran dan model pembelajaran sangatlah erat hubungannya, karena penggunaan model pembelajaran yang tepat akan menghasilkan 
proses pembelajaran yang tepat juga. Selain penggunaan model pembelajaran yang tepat, hal yang tak dapat dihindari adalah bagaimana proses belajar yang dialami oleh para peserta didik itu ditunjang dengan bentuk penilaian yang tepat pula, karena walaupun proses pembelajarannya sudah tepat tetapi jika tidak ditunjang dengan bentuk penilaian yang tepat dapat mengakibatkan keseluruhan proses pembelajaran tidak akan maksimal menghasilkan hasil belajar peserta didik yang maksimal pula. Oleh karena itu, bagi setiap siswa yang telah memiliki kemampuan pemecahan masalah yang berkaitan dengan materi pembelajaran matematika akan sangat membantu proses pemahaman atau pembentukan pengetahuan baru bagi siswa. Demikian pula jika pemakaian bentuk penilaian dengan kurangnya kemampuan pemecahan masalah matematis maka hal ini akan menjadi penghambat bagi pembentukan konsep atau pengetahuan yang baru. Dengan demikian dapat disimpulkan bahwa model pembelajaran dan bentuk penilaian serta jenis sekolah mempengaruhi kemampuan pemecahan masalah matematis siswa.

Berdasarkan uraian yang dikemukakan di atas, maka tujuan utama peneltian ini adalah untuk mengetahui pengaruh model pembelajaran Quantum Teaching dan bentuk penilaian portofolio berbasis kelas serta jenis sekolah terhadap kemampuan pemecahan masalah matematis siswa.

\section{METODE PENELITIAN}

Metode yang digunakan dalam penelitian ini adalah metode eksperimen dengan desain faktorial $2 \times 2$. Dengan desain berikut:

Tabel 1. Desain Eksperimen

\begin{tabular}{cccc}
\hline & & \multicolumn{2}{c}{ Model Pembelajaran Quantum Teaching } \\
\hline & & Sekolah Dasar & Madrasah Ibtidaiyah \\
& $\mathbf{A}_{1}$ & $\mathbf{A}_{2}$ \\
\hline Bentuk & Tampilan & $\mathrm{A}_{1} \mathrm{~B}_{1}$ & $\mathrm{~A}_{2} \mathrm{~B}_{1}$ \\
Penilaian & $\mathrm{B}_{1}$ & $\mathrm{~A}_{1} \mathrm{~B}_{2}$ & $\mathrm{~A}_{2} \mathrm{~B}_{2}$ \\
Portofolio & $\begin{array}{c}\text { Dokumen } \\
\mathrm{B}_{2}\end{array}$ & & \\
\hline
\end{tabular}

Keterangan : $A_{1} B_{1}=$ Kelompok siswa SD yang diberikan model

pembelajaran Quantum Teaching dan bentuk penilaian portofolio tampilan.

$\mathrm{A}_{2} \mathrm{~B}_{1}=$ Kelompok siswa MI yang diberikan model pembelajaran Quantum Teaching dan bentuk penilaian portofolio tampilan 
$\mathrm{A}_{1} \mathrm{~B}_{2}=$ Kelompok siswa SD yang diberikan model

pembelajaran Quantum Teaching dan bentuk penilaian

portofolio dokumen.

$\mathrm{A}_{2} \mathrm{~B}_{2}=$ Kelompok siswa MI yang diberikan model

pembelajaran Quantum Teaching dan bentuk penilaian

portofolio dokumen.

Populasi dalam penelitian ini adalah seluruh siswa kelas V SDN Karanganyar Indramayu dan MI Indramayu dengan jumlah 8 kelas. Kedua sekolah tersebut terdapat pada satu kota yaitu kota Kabupaten Indramayu Propinsi Jawa Barat.

Sampel penelitian ditentukan dengan menggunakan teknik multistage random sampling. Instrumen penelitian yang dikembangkan adalah instrumen kemampuan pemecahan masalah matematis dalam bentuk soal esay berjumlah 6 butir soal. Proses validasi empirik adalah melalui ujicoba instrumen kemampuan pemecahan masalah matematis di lapangan melibatkan 100 orang siswa kelas VI. Berdasarkan penghitungan uji validitas diperoleh hasil: dari jumlah 6 butir soal yang diujicobakan diperoleh 6 butir soal semuanya dengan status valid dengan koefisien reliabilitas sebesar 0,72.

\section{HASIL DAN PEMBAHASAN}

Teknik analisis data menggunakan ANAVA dua jalan diperoleh:

Tabel 2. Rangkuman Deskripsi Data Kemampuan Pemecahan Masalah Matematika Siswa

\begin{tabular}{|c|c|c|c|c|c|}
\hline & & & Pembelajar & Iantum Teaching & \\
\hline & & & $\begin{array}{c}\text { Sekolah Dasar } \\
\text { (A1) }\end{array}$ & $\begin{array}{c}\text { Madrasah Ibtidaiyah } \\
\text { (A2) }\end{array}$ & Total \\
\hline & & $n$ & 10 & 10 & 20 \\
\hline & Tampilan & Mean & 79,8 & 73 & 76,4 \\
\hline & (B1) & Min & 67 & 60 & 60 \\
\hline Bentuk & & $\operatorname{Max}$ & 100 & 87 & 87 \\
\hline Penilaian & & $n$ & 10 & 10 & 20 \\
\hline Portorol10 & Dokumen & Mean & 70,7 & 51,6 & 61,15 \\
\hline & (B2) & Min & 57 & 23 & 23 \\
\hline & & $\operatorname{Max}$ & 90 & 77 & 90 \\
\hline & & $n$ & 20 & 20 & \\
\hline & & Mean & 75,25 & 62,3 & \\
\hline & & Min & 57 & 60 & \\
\hline & & $\operatorname{Max}$ & 100 & 87 & \\
\hline
\end{tabular}

Keterangan:

A1 : kelompok siswa Sekolah Dasar

A2 : kelompok siswa Madrasah Ibtidaiyah 
B1 : kelompok siswa yang diberikan penilaian portofolio tampilan

B2 : kelompok siswa yang diberikan penilaian portofolio dokumen

n : banyaknya sampel

Min: skor minimum

Max: skor maksimum

\section{Pengujian Hipotesis Faktor Utama (Main Effect)}

Hipotesis faktor utama (main effect) yang diuji adalah sebagai berikut:

1. Kemampuan pemecahan masalah matematis antara kelompok siswa sekolah dasar lebih tinggi dari kelompok siswa madrasah ibtidaiyah.

Hipotesis statistiknya: $\mathrm{H}_{\mathrm{o}}: \mu_{\mathrm{A} 1} \leq \mu_{\mathrm{A} 2}$ dan $\mathrm{H}_{1}: \mu_{\mathrm{A} 1}>\mu_{\mathrm{A} 2}$

Hasil perhitungan diperoleh $\mathrm{F}_{\text {hitung }}=4,37>\mathrm{F}_{\text {tabel }}=3,97$ pada $\alpha=0,05$ maka $\mathrm{H}_{\mathrm{o}}$ ditolak dan menerima $\mathrm{H}_{1}$. Ini berarti bahwa terdapat perbedaan kemampuan pemecahan masalah matematis antara kelompok siswa sekolah dasar $\left(\mu_{\mathrm{A} 1}=75,25\right)$ dengan kelompok siswa madrasah ibtidaiyah $\left(\mu_{\mathrm{A} 2}=62,3\right)$. Dengan demikian dapat disimpulkan bahwa kemampuan pemecahan masalah matematis antara kelompok siswa sekolah dasar lebih tinggi dari kelompok siswa madrasah ibtidaiyah.

2. Kemampuan pemecahan masalah matematis antara kelompok siswa yang diberi penilaian portofolio tampilan lebih tinggi dari kelompok siswa yang diberi penilaian portofolio dokumen.

Hipotesis statistiknya: $\mathrm{H}_{\mathrm{o}}: \mu_{\mathrm{B} 1} \leq \mu_{\mathrm{B} 2}$ dan $\mathrm{H}_{1}: \mu_{\mathrm{B} 1}>\mu_{\mathrm{B} 2}$

Hasil perhitungan diperoleh $\mathrm{F}_{\text {hitung }}=5,22>\mathrm{F}_{\text {tabel }}=3,97$ pada $\alpha=0,05$ maka $\mathrm{H}_{\mathrm{o}}$ ditolak dan menerima $\mathrm{H}_{1}$. Ini berarti bahwa terdapat perbedaan kemampuan pemecahan masalah matematis antara kelompok siswa yang diberi penilaian portofolio tampilan $\left(\mu_{\mathrm{B} 1}=76,4\right)$ dengan kelompok siswa yang diberi penilaian portofolio dokumen $\left(\mu_{\mathrm{B} 2}=61,15\right)$. Dengan demikian dapat disimpulkan bahwa kemampuan pemecahan masalah matematis antara kelompok siswa yang diberi penilaian portofolio tampilan lebih tinggi dari kelompok siswa yang diberi penilaian portofolio dokumen.

\section{Pengujian Hipotesis Interaksi (Interaction Effect)}

Pengaruh interaksi model pembelajaran Quantum Teaching antara bentuk penilaian portofolio dengan jenis sekolah terhadap kemampuan pemecahan masalah matematis siswa.

Hipotesis statistiknya: $\mathrm{Ho}$ : Interaksi $\mathrm{A} \times \mathrm{B}=0$ dan $\mathrm{H}_{1}$ : Interaksi $\mathrm{A} \times \mathrm{B} \neq 0$ 
Hasil analisis: $\mathrm{F}_{\text {hitung }}=0,09<\mathrm{F}_{\text {tabel }(0,05)}=3,97$ yang berarti $\mathrm{H}_{\mathrm{o}}$ diterima dan menolak $\mathrm{H}_{1}$. Dengan demikian disimpulkan tidak ada pengaruh interaksi model pembelajaran Quantum Teaching antara bentuk penilaian portofolio dengan jenis sekolah terhadap kemampuan pemecahan masalah matematis siswa.

\section{Pengujian Lanjut Hipotesis Sederhana (Simple Effect)}

1. Pada kelompok siswa yang diberi model pembelajaran Quantum Teaching dan yang diberikan penilaian portofolio tampilan, kemampuan pemecahan masalah matematis kelompok siswa sekolah dasar lebih tinggi dari kelompok siswa madrasah ibtidaiyah.

Hipotesis statistiknya: $\mathrm{Ho}: \mu_{\mathrm{A} 1 \mathrm{~B} 1} \leq \mu_{\mathrm{A} 2 \mathrm{~B} 1}$ dan $\mathrm{H}_{1}: \mu_{\mathrm{A} 1 \mathrm{~B} 1}>\mu_{\mathrm{A} 2 \mathrm{~B} 1}$

Hasil perhitungan diperoleh $\mathrm{t}_{\text {hitung }}=1,098<\mathrm{t}_{\mathrm{tab}(1,9))}=1,694$ pada $\alpha=0,05$ maka $\mathrm{H}_{\mathrm{o}}$ diterima dan menolak $\mathrm{H}_{1}$. Ini berarti bahwa pada kelompok siswa yang diberi model pembelajaran Quantum Teaching dan yang diberikan penilaian portofolio tampilan, tidak terdapat perbedaan kemampuan pemecahan masalah matematis antara kelompok siswa sekolah dasar $\left(\mu_{\mathrm{A} 1 \mathrm{~B} 1}=79,8\right)$ dengan kelompok siswa madrasah ibtidaiyah $\left(\mu_{\mathrm{A} 2 \mathrm{~B} 1}=73,0\right)$. Dengan demikian dapat disimpulkan bahwa untuk kelompok siswa yang diberi model pembelajaran Quantum Teaching dan yang diberikan penilaian portofolio tampilan, kemampuan pemecahan masalah matematis kelompok siswa sekolah dasar tidak lebih tinggi dari kelompok siswa madrasah ibtidaiyah.

2. Pada kelompok siswa yang diberi model pembelajaran Quantum Teaching dan yang diberikan penilaian portofolio dokumen, kemampuan pemecahan masalah matematis kelompok siswa sekolah dasar lebih tinggi dari kelompok siswa madrasah ibtidaiyah.

Hipotesis statistiknya: $\mathrm{Ho}: \mu_{\mathrm{A} 1 \mathrm{~B} 2} \geq \mu_{\mathrm{A} 2 \mathrm{~B} 2}$ dan $\mathrm{H}_{1}: \mu_{\mathrm{A} 1 \mathrm{~B} 2}<\mu_{\mathrm{A} 2 \mathrm{~B} 2}$

Hasil perhitungan diperoleh $\mathrm{t}_{\text {hitung }}=3,084>\mathrm{t}_{\mathrm{tab}(1,9))}=1,694$ pada $\alpha=0,05$ maka $\mathrm{H}_{\mathrm{o}}$ ditolak dan menerima $\mathrm{H}_{1}$. Ini berarti bahwa pada kelompok siswa yang diberi model pembelajaran Quantum Teaching dan yang diberikan penilaian portofolio dokumen, terdapat perbedaan kemampuan pemecahan masalah matematis antara kelompok siswa sekolah dasar $\left(\mu_{\mathrm{A} 1 \mathrm{~B} 2}=70,7\right)$ dengan kelompok siswa madrasah ibtidaiyah $\left(\mu_{\mathrm{A} 2 \mathrm{~B} 1}=51,6\right)$. Dengan demikian dapat disimpulkan bahwa untuk kelompok siswa yang diberi model pembelajaran Quantum Teaching dan yang diberikan penilaian portofolio dokumen, kemampuan pemecahan masalah matematis kelompok siswa sekolah dasar lebih tinggi dari kelompok siswa madrasah ibtidaiyah. 
3. Pada kelompok siswa sekolah dasar yang diberi model pembelajaran Quantum Teaching, kemampuan pemecahan masalah matematis kelompok siswa yang diberi penilaian portofolio tampilan lebih tinggi dari kelompok siswa yang diberi penilaian portofolio dokumen.

Hipotesis statistiknya: $\mathrm{Ho}_{0} \mu_{\mathrm{A} 1 \mathrm{~B} 1} \leq \mu_{\mathrm{A} 1 \mathrm{~B} 2}$ dan $\mathrm{H}_{1}: \mu_{\mathrm{A} 1 \mathrm{~B} 1}>\mu_{\mathrm{A} 1 \mathrm{~B} 2}$

Hasil perhitungan diperoleh $\mathrm{t}_{\text {hitung }}=1,47<\mathrm{t}_{\mathrm{tab}(1,9))}=1,694$ pada $\alpha=0,05$ maka $\mathrm{H}_{\mathrm{o}}$ diterima dan menolak $\mathrm{H}_{1}$. Ini berarti bahwa pada kelompok siswa sekolah dasar yang diberi model pembelajaran Quantum Teaching, tidak terdapat perbedaan kemampuan pemecahan masalah matematis kelompok siswa yang diberi penilaian portofolio tampilan $\left(\mu_{\mathrm{A} 1}=79,8\right)$ dengan kelompok siswa yang diberi penilaian portofolio dokumen $\left(\mu_{\mathrm{A} 2}=70,7\right)$. Dengan demikian dapat disimpulkan bahwa untuk kelompok siswa sekolah dasar yang diberi model pembelajaran Quantum Teaching, kemampuan pemecahan masalah matematis kelompok siswa yang diberi penilaian portofolio tampilan tidak lebih tinggi dari kelompok siswa yang diberi penilaian portofolio dokumen.

4. Pada kelompok siswa madrasah ibtidaiyah yang diberi model pembelajaran Quantum Teaching, kemampuan pemecahan masalah matematis kelompok siswa yang diberi penilaian portofolio tampilan lebih tinggi dari kelompok siswa yang diberi penilaian portofolio dokumen.

Hipotesis statistiknya: Ho : $\mu_{\mathrm{A} 2 \mathrm{~B} 1} \geq \mu_{\mathrm{A} 2 \mathrm{~B} 2}$ dan $\mathrm{H}_{1}: \mu_{\mathrm{A} 2 \mathrm{~B} 1}<\mu_{\mathrm{A} 2 \mathrm{~B} 2}$

Hasil perhitungan diperoleh $\mathrm{t}_{\text {hitung }}=3,46>\mathrm{t}_{\mathrm{tab}(1,9))}=1,694$ pada $\alpha=0,05$ maka $\mathrm{H}_{\mathrm{o}}$ ditolak dan menerima $\mathrm{H}_{1}$. Ini berarti bahwa pada kelompok siswa madrasah ibtidaiyah yang diberi model pembelajaran Quantum Teaching, terdapat perbedaan kemampuan pemecahan masalah matematis kelompok siswa yang diberi penilaian portofolio tampilan $\left(\mu_{\mathrm{A} 1}=73,0\right)$ dengan kelompok siswa yang diberi penilaian portofolio dokumen $\left(\mu_{\mathrm{A} 2}=51,6\right)$. Dengan demikian dapat disimpulkan bahwa untuk kelompok siswa madrasah ibtidaiyah yang diberi model pembelajaran Quantum Teaching, kemampuan pemecahan masalah matematis kelompok siswa yang diberi penilaian portofolio tampilan lebih tinggi dari kelompok siswa yang diberi penilaian portofolio dokumen

\section{Pembahasan Hasil Penelitian}

Hasil peneltian ini memperlihatkan bahwa kemampuan pemecahan masalah matematis kelompok siswa yang diberi penilaian portofolio tampilan lebih tinggi dari kemampuan pemecahan masalah matematis kelompok siswa yang diberi penilaian portofolio dokumen. Kelebihan portofolio tampilan adalah siswa mempresentasikan hasil 
kerjanya di depan guru dan siswa lainnya. Pada portofolio tampilan kemempuankemampuan tersebut dapat dikembangkan karena siswa pada portofolio ini diberi kesempatan untuk mendemonstrasikan kemampuannya dalam menyelesaikan masalah di depan guru dan siswa yang lainnya. Pada portofolio dokumen siswa tidak memperoleh kesempatan tersebut. Sejalan dengan penelitian yang dilakukan oleh Sukmawati (2014) bahwa kemampuan pemecahan masalah matematis kelompok siswa yang diberi penilaian portofolio tampilan lebih tinggi dari kemampuan pemecahan masalah matematis kelompok siswa yang diberi penilaian portofolio dokumen.

Model pembelajaran Quantum Teaching ini merupakan model pembelajaran yang ideal, karena menekankan kerjasama antar siswa dan guru untuk mencapai tujuan bersama. Hal ini menunjukkan bahwa pembelajaran Quantum Teaching menekankan kegiatannya pada pengembangan potensi siswa secara optimal melalui cara-cara yang sangat manusiawi, yaitu mudah, menyenangkan, dan memberdayakan. Hasil penelitian Murni, dkk. (2013) menunjukkan bahwa penerapan model pembelajaran Quantum Teaching tipe TANDUR dapat meningkatkan hasil belajar siswa dalam pembelajaran Matematika di kelas IV. Hal ini senada dengan Prasetyani, dkk. (2012) dalam penelitiannya menyatakan bahwa terdapat perbedaan hasil belajar siswa antara penggunaan model Quantum Teaching dan metode konvensional dimana siswa yang memperoleh pembelajaran Quantum Teaching mendapatkan nilai hasil belajar yang baik.

Hal ini menunjukan bahwa pembelajaran Quantum Teaching menekankan kegiatannya pada pengembangan potensi siswa secara optimal melalui cara-cara yang sangat manusiawi, yaitu mudah, menyenangkan, dan memberdayakan. Pembelajaran Quantum Teaching yang diterapkan di kelas merupakan analogi dengan kegiatan yang melibatkan setiap siswa dalam pembelajaran kelompok dalam menyelesaikan tugas belajarnya, sehingga mendorong setiap siswa mngekspresikan kemampuannnya melalui pemecahan masalah soal-soal yang dikerjakan. Oleh karena itu, proses pembelajaran yang melibatkan sikap, nilai, dan keyakinan siswa ini diharapkan dapat mengarahkan pada kesadaran melalui keterlibatan spontan siswa dalam proses pembelajaran.

Pada penilaian portofolio tampilan siswa mempunyai motivasi untuk berbuat lebih baik dan berusaha untuk mengerjakan secara maksimal karena hasil kerjanya akan ditampilkan dan akan ditanggapi oleh siswa lain. Portofolio tampilan ini juga dijelaskan oleh Cole, et al (1995) sebagai sekumpulan hasil kerja siswa atau dokumen yang terseleksi yang dipersiapkan untukditampilkan di depan umum, seperti misalnya 
mempertanggungjawabkan suatu proyek, menyelenggarakan pameran atau mempertahankan suatu konsep. Seperti yang dikemukakan Surapranata (2006) portofolio dokumentasi adalah koleksi hasil kerja siswa yang khusus digunakan untuk penilaian, atau koleksi dari sekumpulan hasil kerja siswa selama kurun waktu tertentu. Portofolio dokumen tidak hanya berisi hasil kerja siswa, tetapi semua proses yang digunakan oleh siswa untuk menghasilkan karya tertentu, juga berisi berbagai macam draf dan komentar siswa tentang hasil karya dari proses sampai di hasilkannya karya tersebut.

Pada penilaian portopolio dokumen pada dasarnya merupakan proses kerja siswa terhadap pekerjaan siswa secara individu untuk melihat perkembangan kemampuannya terhadap mata pelajaran matematika pada setiap satu kompetensi dasar. Pada penilaian portofolio dokumen siswa mendokumenkan hasil kerjanya pada suatu folder. Hasil kerja siswa tersebut berupa hasil kerja yang berupa tugas-tugas yang diberikan oleh guru. Pada penilaian portofolio dokumen ini siswa diberi kesempatan untuk melakukan refleksi terhadap hasil kerjanya. Refleksi ini dimaksudkan untuk membuat siswa dapat memikirkan tentang cara siswa memecahkan masalahnya. Namun pada penilaian portofolio dokumen ini siswa tidak dapat maksimal dalam melakukan refleksi terhadap pemecahan masalahnya, karena pada portofolio dokumen ini hanya mendokumenkan hasil kerjanya yang hanya akan digunakan sebagai bukti untuk penilaian. Dari hasil pengamatan, siswa sangat antusias pada penilaian portofolio tampilan. Siswa mempersiapkan hasil kerjanya yang akan mereka tampilkan dengan sungguh-sungguh, mulai dari materi persoalannya, kesesuaian pemecahan masalah yang dibahas sampai pada saat presentasi mereka secara bergantian ingin menampilkan kemampuannya didepan kelas.

\section{KESIMPULAN}

Temuan yang diperoleh pada penelitian ini adalah kemampuan pemecahan masalah matematis antara kelompok siswa sekolah dasar lebih tinggi dari kelompok siswa madrasah ibtidaiyah. Kemampuan pemecahan masalah matematis antara kelompok siswa yang diberi penilaian portofolio tampilan lebih tinggi dari kelompok siswa yang diberi penilaian portofolio dokumen. Tidak ada pengaruh interaksi model pembelajaran Quantum Teaching antara bentuk penilaian portofolio dengan jenis sekolah terhadap kemampuan pemecahan masalah matematis siswa.

Untuk kelompok siswa yang diberi model pembelajaran Quantum Teaching dan yang diberikan penilaian portofolio tampilan, kemampuan pemecahan masalah matematis 
kelompok siswa sekolah dasar tidak lebih tinggi dari kelompok siswa madrasah ibtidaiyah. Untuk kelompok siswa yang diberi model pembelajaran Quantum Teaching dan yang diberikan penilaian portofolio dokumen, kemampuan pemecahan masalah matematis kelompok siswa sekolah dasar lebih tinggi dari kelompok siswa madrasah ibtidaiyah. Untuk kelompok siswa sekolah dasar yang diberi model pembelajaran Quantum Teaching, kemampuan pemecahan masalah matematis kelompok siswa yang diberi penilaian portofolio tampilan tidak lebih tinggi dari kelompok siswa yang diberi penilaian portofolio dokumen. Untuk kelompok siswa madrasah ibtidaiyah yang diberi model pembelajaran Quantum Teaching, kemampuan pemecahan masalah matematis kelompok siswa yang diberi penilaian portofolio tampilan lebih tinggi dari kelompok siswa yang diberi penilaian portofolio dokumen.

\section{DAFTAR PUSTAKA}

Arifin, Z. (2009). Evaluasi Pembelajaran Prinsip dan Prosedur. Bandung: PT. Remaja Rosdakarya.

Butler, S. M. \& BcMunn, N. D. (2006). A Teacher's Guide to Classroom Assessment: Understanding and Using Assessment to Improve Student Learning. San Francisco: Jossey-Bass.

Cole, D. J., Ryan, C.W., \& Kick, F. (1995). Portfolios Accross the Curriculum and Beyond. Thousan Oaks, CA: Cormin Press.

DePorter, B., Reardon, M., \& Singer-Nourie, S. (2002). Quantum Teaching, Mempraktikkan Quantum Learning di Ruang-Ruang Kelas (Diterjemahkan Ary Nilandari). Bandung: Kaifa.

Hadi, S. (2005). Pendidikan Matematika Realistik dan Implikasinya. Banjarmasin: Tulip.

A. Hendriana, H. \& Sumarmo, U. (2014). Penilaian Pembelajaran Matematika. Bandung: Refika Aditama.

Hudojo, H. (1988). Mengajar Belajar Matematika. Jakarta: Departemen Pendidikan Nasional.

Husamah \& Setyaningrum, Y. (2013). Desain Pembelajaran Berbasis Pencapaian Kompetensi Panduan Merancang Pembelajaran Untuk Mendukung Implementasi Kurikulum 2013. Jakarta: Prestasi Pustakarya.

Johnson, D \& Rising, G. (1987). Guide Lines for Teaching Mathematics. California: Wad Worth Publishing Co.

Margono, G. (2007). Keterkaitan antara Problem Solving dengan Kreativitas dalam Pembelajaran Matematika. Algoritma Jurnal Matematika dan Pendidikan Matematika, Vol. 2, No.1, 45-62.

Murni, Sri, I., Ngatman, \& Chamdani. (2013). Penggunaan Model Pembelajaran Quantum Teaching Tipe TANDUR dalam Peningkatan Hasil Belajar Matematika di Kelas IV SD Negeri Madurejo. Surakarta: PGSD FKIP UNS.

Ormrod, E. J. (2009). Educational Psychology Developing Learners (Diterjemahkan Wahyu Indianti). Jakarta: Erlangga.

Popham, W. J. (1995). Classroom Assessment: What Teacher Need to Know. Boston: Allyn and Bacon. 
Prasetyani, Y., Hadi, S., \& Marimin, M. (2012). Perbedaan Penerapan Model Pembelajaran Quantum Teaching dengan Metode Konvensional dalam Hasil Belajar Siswa. Economic Education Analysis Journal: EEAJ, Vol 1, No.2, 1-6.

Shadiq, F. (2014). Pembelajaran Matematika Cara Meningkatkan Kemampuan Berpikir Siswa. Yogyakarta: Graha Ilmu.

Soedjadi, R. (2000). Kiat Pendidikan Matematika di Indonesia. Jakarta: Departemen Pendidikan Nasional.

Solso, R. L., Maclin, O. H., \& Maclin, M. K. (2005). Cognitive Psychology. Boston: Allyn and Bacon.

Sukmawati. (2014). Pengaruh Model Asesmen Portofolio dan Kreativitas terhadap Kemampuan Pemecahan masalah matematis Siswa SMA Negeri Makasar. Disertasi pada Program Pascasarjana UNJ: Tidak diterbitkan.

Surapranata, S. (2006). Pedoman pengembangan Penilaian Portofolio. Jakarta: Pusat Penilaian Pendidikan Badan Penelitian dan Pengembangan Departemen Pendidikan Nasional.

Suriasumantri, J. S. (2009). Filsafat Ilmu Sebuah Pengantar Populer. Jakarta: Pustaka Sinar Harapan.

Wijaya, A. (2012). Pendidikan Matematika Realistik Suatu Alternatif Pendekatan Pembelajaran Matematika. Yogyakarta: Graha Ilmu. 